\title{
Message from the Host University
}

$18^{\text {th }}$ December, 2018

Welcome to the International Conference on Mathematics (ICM 2018) at Ton Duc Thang University (TDTU), Ho Chi Minh City, Vietnam. This conference aims to offer a forum for university academics, scholars, and researchers from around the world to share their knowledge and latest results in the advanced topics of Pure and Applied Mathematics. The conference is held every two years at Ton Duc Thang University. This year, the themes of the conference have been selected to cover the areas of Algebra, Numerical Analysis, Applied Analysis and Statistics.

Founded in 1997, TDTU has become a visionary, pioneering, and fast-growing university in Vietnam. Over the past 21 years, TDTU has demonstrated excellence in academic performance. As a comprehensive university, TDTU focuses to improve the quantity and quality of research output by establishing many research centers and cooperating with international scholars. As a result, TDTU is now ranked among the largest and fastest developing universities in Vietnam in all aspects. In 2017, TDTU was ranked second among Vietnamese universities and first among those with regards to scientific research. In 2018, The High Council for Evaluation of Research and Higher Education (HCÉRES) recognized that TDTU complies with French and European standards for universities. In the same year, TDTU was honored to be the first public university in Vietnam to be officially rated 4 out of 5 stars under the QS Stars (UK) standard.

On behalf of TDTU, the host institution of ICM 2018, I would like to express my sincere appreciation to our honorable partners: Incheon National University, Republic of Korea; Mississippi State University, USA; VŠB - Technical University of Ostrava, the Czech Republic; and Wrocław University of Science and Technology, Poland, for their great efforts in co-organizing this conference. I would also like to send my special thanks to conference chairs, committees, reviewers, speakers, authors and participants around the world for their contributions and interest in our event.

I believe that you will have an interesting and fruitful conference in Vietnam. I really look forward to welcoming all of you to our campus and hope that this conference will start a long-term partnership between you and our university.

Prof. Le Vinh Danh, Ph.D.

President

Ton Duc Thang University, Vietnam

(C) The Authors, published by EDP Sciences. This is an open access article distributed under the terms of the Creative Commons Attribution License 4.0 (http://creativecommons.org/licenses/by/4.0/). 